\title{
MILAN RASTISLAV ŠTEFÁNIK IN THEATRE PRODUCTIONS IN SLOVAKIA AND THE CZECH REPUBLIC

\author{
Dagmar Inštitorisová ${ }^{1}$
}

\begin{abstract}
This paper contains a review of plays featuring Milan Rastislav Stefanik as the main character. It involves accessible examples of Slovak and Czech plays, which portray Stefanik as having features of a dramatic character. The paper concentrates on both contemporary plays and those emerging soon after his death. The staging of contemporary plays is analyzed with a focus on dramatic texts and plays that are mainly ceremonial and educational. These were performed, predominantly, in school environments or during celebrations commemorating Stefanik's tragic death. The paper begins with a short biography of Štefánik.
\end{abstract}

UDC Classification: 7.01/.09, 7.091, 7.06; DOI: http://dx.doi.org/10.12955/cbup.v6.1222

Keywords: Milan Rastislav Stefanik, dramatic character, theatre, Slovak and Czech drama

\section{Brief Biography of Milan Rastislav Štefánik}

Milan Rastislav Štefánik (born Jul 21, 1880, at Košariská, died May 4, 1919, at Ivánka pri Dunaji) was an astronomer, politician, a General in the French army, and first Czechoslovak Minister of War.

He was born to a Lutheran pastor, Pavel Štefánik, and his wife, Albertina. He studied, with excellent results, at the Evangelical Lyceum in Bratislava and at high schools in Sopron and Szarvas, where he graduated in 1898. From 1898, he studied civil engineering and astronomy at the Philosophical Faculty of Charles University in Prague. He was engaged in the work of the Detvan Society where he presided in 1901. He was an ardent supporter of the Group of Hlasists and ideas of Tomás Garrigue Masaryk. Since 1904, he worked in Paris. Owing to Professor Jules Janssen, he worked at Meudon Observatory and participated in many expeditions (Mont Blanc, Alcossebre in Spain) and began intensive publishing work, including in scientific magazines. In 1907, he received the Janssen Award from the French Astronomical Society for his work on numerous occasions at Mont Blanc Observatory. In 1910, the scientific institutes of The Bureau des Longitudes and Le Bureau Central Météorologique entrusted him to lead an expedition to observe Halley's Comet in Tahiti, where he established the foundations of the Tahitian observatory and meteorological station. In 1912, he became a French citizen. For his scientific work, he was awarded prizes from the French Astronomical Society, the Janssen Award and Wilde Award of the French Academy of Sciences. For scientific and diplomatic achievements, he was awarded the Grand Officer of the Legion of Honor by the French government (1914) and the Imperial Russian military command awarded him the highest award, The Order of Saint Vladimir (1918).

With the major politicians, Tomáš Garrigue Masaryk and Eduard Beneš Štefánik, he founded, in February 1916 in Paris, the Czechoslovak National Council. He was actively involved as an aviator in the fighting of World War I and became colonel of the French army. In 1918, he became the Minister of War in the Czechoslovak government. After much effort, he managed to establish, in 1917, the Czechoslovak Army (10000 soldiers). One of the last major achievements of Štefánik was the negotiations of the return of the Czechoslovak legions from Russian Siberia in 1919.

Štefánik's life ended tragically early when during his return home his plane suddenly crashed in Ivánka pri Dunaji.

\section{Theatre Productions and Štefánik}

The theatre is closely linked to Milan Rastislav Štefánik in the context of his public activity and personal life. Similar to other members of the Prague Detvan Society, during his university studies in Prague, he was, for example, an eager debater about criticism and studying of new aesthetics of realism (Mistrík, 1999, p. 16). Criticism of the theatrical plays created by members of the Detvan Society was an indivisible part of some meetings. From the minutes of the Detvan Society meetings and from personal records of the writer and playwright, Jozef Gregor Tajovský (Šujan, 1928, p. 90), historians identified a comment about a critical essay written by Štefánik that was at one of the society's meetings on December 10, 1898. Vavro Šrobár, Štefánik, and certain other Detvan Society members had been highly critical of some plays and Tajovský reacted by burning them (Štefko, 2001,

\footnotetext{
${ }^{1}$ Katedra masmediálnej komunikácie a reklamy, Filozofická fakulta Univerzity Konštantína Filozofa v Nitre, dinstitorisova@ukf.sk
} 
p. 77). Štefánik stated that the main character was missing, there were mistakes in the structure of the play, that it was not dramatic enough, it lacked gradation, and was too long in the second part (Štefko, 2001, p. 77).

Štefánik frequently visited Prague's theaters and those of other countries. His personal library contained, for example, copies of plays by Molière (Sabov, 2010, p. 265). During his visit to Ecuador in 1913, French ambassador Francastel most likely recited his translations of Shakespeare, poems, and dramas to Štefánik (Štefánik, 1935, p. 259). Štefánik was considering translating a drama of the writer, Eudofil Alvarez. According to Štefánik (1935, p. 253), Štefánik wrote on November 27 “...this drama takes place between Indians in Orient, where Alvarez has traveled recently." He also assumed he could present the play on some stage.

The open line of Štefánik's life is bound with the emergence of several plays that were traditional dramas and theatrical productions, with dramatic shapes (variations) of different characters (scenes, skits, choral recitation, vivid images, and libretti). These were and still are mainly reported on the anniversary of Štefánik's death.

\section{Image of Štefánik}

The character of Milan Rastislav Štefánik varies between Slovak and Czech dramatic works and theater plays. His personality dominates stage works mostly in Slovakia. This was quite significant in the first decade after his death. Dramatic works depicting his personality after his death were quite extensively performed by Czech male and female dramatic writers, not only Slovak ones. Some published their dramatic works in Slovakia, e.g., Růžena Blahoutová-Pospíšilová, Alojz Zbavitel, and others. Today, not surprisingly, Slovak staging and drama continue to dominate.

The first plays, sketches, and other dramatic forms and productions devoted to the premature death of Milan Rastislav Štefánik are described in great detail by Peter Macho in his monograph Milan Rastislav Štefánik $v$ hlavách a $v$ srdciach. Fenomén národného hrdinu v historickej pamäti (Milan Rastislav Štefánik in the Heads and Hearts. The Phenomenon of a National Hero in a Historical Memory). This was especially connected to organizing various charity performances in Trnava. The profit from these performances was invested in constructing a monument in Štefánik's honor in Trnava in 1924 (Macho, 2011, p. 75). The main organizers of the theatrical performances were "... societies and schools ..." (Macho, 2011, p. 88), which also organized charity balls and other events to raise funds for building the monument (Macho, 2011, p. 88).

Among the main organizers and initiators of various celebrations in Štefánik's honor in Trnava was the then famous Slovak amateur theater director, writer, and publisher of theater plays, Ferko Urbánek $^{2}$ from Trnava, who published several biographical plays about Štefánik. Urbánek mentioned Štefánik in his plays, Hriešnica (Sinner) of 1930 and Za slobodu (For Freedom) of 1934. The play For Freedom was a dramatic fragment with the theme of legions and legionaries and was part of the program at special celebrations in 1922. It was performed at a ceremonial remembrance on the anniversary of the death of Štefánik and was co-organized by Urbanek as chairman of the Slovak National Unity. Part of the performance was a live image. This ceremony, along with many others events, was organized in the city's theater (Macho, 2010, pp. 242-243). One play that Urbanek published in honor of Štefánik was translated by French playwright André Germain and called Štefánik (1940). It contained panoramic and symbolic character and dealt with Štefánik's youth, as well as his studies and even his death, to which it dedicated a relatively large part. According to Germain (1940, p. 19), the play aptly portrayed Štefánik's devoted soulful and deep patriotism: "Milan: Resurrect again yours and my joy. Resurrect it and sing to me. Sing me songs that I love so much, those that my mother sang me as a lullaby, those that sooth and calms rivers in Slovakia."

Urbánek had previously published another play about Štefánik linked to the name of the teacher and playwright of Czech origin, Růžena Blahoutová-Pospíšilová, who worked from 1921 to 1939 in Spišská Nová Ves and Hlohovec. Urbánek published the play called Milan Rastislav Štefánik in 1934. It contained a typical biographical character.

\footnotetext{
${ }^{2}$ F. Urbanek was also the publisher of the weekly Slovenský národ (Slovak nation), the President of the Slovak National Unity Party, educator of the Sokol club. He is, for example, also the a uthor of a poem written in his honor.
} 
From the theatrical point of view, a study by Mach (2010), called $K$ vzniku Štefánikovho pomníka v Trnave (About Štefánik's Monument in Trnava), is an interesting reference to another theatrical celebration of Štefánik's death. For example, it reports that at the lecture about Štefánik in 1923 on Wilson's square (now Trinity Square) in Trnava there were illuminated images. This added special attractiveness to the lecture organized by the Prague Resistance Society and the Czechoslovak Legionnaire Community (Macho, 2010, p. 244).

Several plays, role-plays, and vivid images that were created during the First Republic present mostly a reverent and adoration character and were mostly intended for a school theater. These plays displayed a reverence of Štefánik, emphasized his efforts to create a common state with Czechs, military successes, and patriotism, and depicted his career as a scientist. For example, Čestmír Vránek (1933) frequently mentioned Štefánik's native village, Košariská, and his family, especially his mother in the short play Štefánikova matka (Štefánik's Mother):

MOTHER: It happened once in the morning and we were getting ready to have lunch. But Milanko was nowhere around and it seemed as if he fell into the water. We were looking for him, calling him, looking everywhere outside in the yard, garden, school, cemetery, around the village, but all in vain, in vain. I've been out of myself with fear. That is when bell-boys found him when they went to ring at noon, in the church tower just when he was going down. When I asked him what he was doing there he told me in full seriousness I was looking at little stars. (p. 16)

As another example, an interesting interpretation of Štefánik's stay in Haiti was given in the drama Štefánik na Tahiti (Štefánik at Tahiti) by Štefan Sabol (1938), in which the character of Štefánik talks about national ideals with an educated black person, who is very knowledgeable about issues of national consciousness. In the end, this person's friend, Fero, arrives and informs him about the fact that the war had just broken. Štefánik perceives in that a great opportunity for Slovaks and Czechs, and it becomes his incentive to return to Europe. The dramatic text also includes the typical romantic interpretation of Štefánik's life and greatness. In the play by Ondrej Zemančík (1938), Hrdinov odkaz, (Hero's Message) there are fairy-tale creatures of dwarfs (including their King) and fairies who swear their allegiance to the national hero at a place near the Štefánik's monument, with an inscription 'Believe, Love and Work' ${ }^{3}$. This play could be considered the most curious of those that are symbolic fairy-tale plays that do not greatly exaggerate in their fabula. The following is from Zemančík (1938):

FUK: (is reading from the thick book) Ages ago our oath which is repeated many times says:

Thousands of years ago wild and evil forces robbed us of your beloved freedom of the Slovak nation. Thousand years we have been looking for it, we were begging, crying, demanding. The Hero had to come who sacrificed his life for the nation shed his blood to his native ground. He came! Behold, there he is in his silent and eternal sleep. (p. 49)

A similar character of a national hero was depicted in the fairy-tale play, Milanovo vitazstvo a smrt' (Milan's Victory and Death), by Ondriš Jariabek (it was subtitled as an allegorical puppet play). This one was written more in line with the traditional construct of a fairy tale. The hero, Milan, frees the Princess of the Republic from the domination of a 'bad witch', Striga Handrbúlka, who conspired with Lucifer and another evil spirit (nicknamed German-Hungarian). The main hero dies in the finale in contrast to a traditional fairy tale ending. In the play, other typical fairy-tale figures of theatre, such as Gašparko, Dragon, and others are depicted by Jariabek (1933):

Gašparko: And you want with your bare hands to smash the rock?

MILAN: Even if I break my hands, I do not care. Just let us do it! Losing any moment is a shame. (Slams into rocks.)

Gašparko: I do not even think about getting my clothes dirty. (Whistling).

MILAN: Hey, Gašparko, Tatran, come, come to help! (p. 165)

Among the dramatic forms that have a solemn and reverent display of adoration is the scene of Štefánik's message based on the words of Stephen Sonderlich and adapted by Ernest Mika in the form of a live image. One of the few dramatic artifacts is seen in this in Miko (1943), where Štefánik speaks as the bust (puppet theater character):

\footnotetext{
${ }^{3}$ Štefánik's slogan and his personal motto.

${ }^{4}$ Fuk figure is a dwarf.
} 
Štefánik: Three words led me living safely in the storm,

Did show me the right direction -

Even if the desires of youth are grabbed by the wild whirlwind,

After the finished work, the heart is at peace. (p. 89)

Typical school plays about Štefánik include four from 1936, Pád oral... (Eagle fall...), 4. 5. 1919 (May 5, 1919), and Památce Milana Rastislava Štefánika (In the Memory of Milan Rastislav Štefánik) by the Czech playwright, Milan Balák, and Pláč hvězd (Crying Stars) by the Czech playwright, Miloš Veselý. Despite his proclaimed Slovak roots, Štefánik was displayed in these as a cosmopolitan character. However, the plays were similar in nature to other Slovak school plays. Eagle Fall... is interesting in that it creates an abstract character of Štefánik, meaning the dramatic character of Štefánik did not appear in the scene in a physical form, but rather in the words of a teacher who prepares his ceremonial speech on his arrival to the school. In the finale, Štefánik 'appears', only as a bust, with sounds of a crashing plane, recital of hymns, and the second part of the national anthem. In the symbolic play, 4. 5. 1919, there are taking place the Destiny, the Soul of the Czechoslovak Republic in which Štefánik does not act again but is present vicariously. It reminisces his grand personality and heroic deeds, and with engine sounds, finally, the bust appears above the boulder with a flag.

The Destiny by Balák (1936) described Štefánik as:

In the wild storm rising around the world -

The brave falcon stood, the son of subjugated country,

For his Motherland with love he fought. (p. 9)

Štefánik's replicas are typically adorative and their style applies to other plays intended for adult audiences.

The play Památce Milana Rastislava Štefánika (In the Memory of Milan Rastislav Štefánik) was the scene of youth performances around the celebratory Štefánik's bust. He is described by episodic means of a monologue about his merits (and life) and festive poems performed by the youth. In the last play, Pláč hvězd (Crying Stars), Štefánik is also present vicariously, when stars (kids) remember his heroic deeds and experience tragically the last moments of his life.

The character of Štefánik in Slovak dramatic formations and productions is never too distorted, the theatrical artifacts try to show him in the regular (even conventional) form. The main features of his personality are love for the Slovak nation, sensitivity, enthusiasm, tenacity, and leadership.

Significantly different to that which is symptomatic of plays by Slovak playwrights, the personality of Štefánik is captured in the play, Bohy milovaný (Loved by Gods) by Czech playwright by Lida Merlinova. Although it is typically a biography, it ends with a brief depiction of his death. The voice in the epilogue informs about his death while the bust on stage is illuminated by a reflector (Merlínová, circa 1926, p. 144). It also contained an unusual showing of Štefánik during the problems at the Mont Blanc observatory. Štefánik and his colleagues could not leave because of bad weather and nearly died of starvation. At the time, Štefánik heard voices that saved them: "VOICES: Now or never! Do you hear! You must come down! Immediately! Now or never!" (Merlínová, circa 1926, p. 38).

The personality of Štefánik appears extraordinary in the contemporary Slovak theatrical production. Apart from the staging of plays themed around the life of the hero, Jánošík, Štefánik is considered the most popular historic figure after 1989. Four plays and four productions have been recently composed around the theme of his life and in some, he is the main character.

The first recent staging was a musical, the minimalist opera of Marek Piaček, Posledný let $s$ podtitulom Dvanást' pohl'adov na M.R.Š (The Last Flight with the subtitle Twelve Views of M R Š), which was based on the libretto of Egon Bondy and Elena Kmet'ová in 2001, staged by the Bratislava Association for Contemporary Opera and directed by Dušan Vicen. The second was a play with songs by Stanislav Štepka called General s podtitulom Príbeh malého vel'kého muža (General, subtitled The Story of the Little Big Man), which was performed in 2004 by Radošinské Naivné Divadlo (Radošina Naive Theatre) and directed by Ondrej Špišák. Before the last play, was the staging of multimedia dance theater, M. R. Štefánik, by librettists Ondrej Šoth and Zuzana Mistríkova. It was directed by Šoth at the State Theatre in Košice in 2009 (Inštitorisová, 2012, s. 42). To date, the last staging of this 
topic was Štefánik - slnko v zatmeni (Štefánik - Solar Eclipse), created and directed by Eva Borušovičová in Andrej Bagar Theatre in Nitra in 2017.

Almost all of these are standard biographical works. The libretto Posledný let focuses on his birth and death symbolically, and it follows in this line mostly the way of Štefánik's thinking (philosophical background, thoughts, and opinions). In this, Bondy and Kmet'ová (2001) show his whole personality and range of personal development, for example:

I feel that this nation is seriously ill. If I do not manage to excel in science, there will not be other option than to become a shepherd, a leader of my people, there, surrounded by those hills that I never stopped loving. It is important to go into the world to fight and suffer. (p. 10)

A similar biographical character is presented in the musical play The General which also follows Štefánik's life from birth to death. Unlike other productions, this play includes an ironic assessment of Štefánik's life and actions. In this, Štepka (2003) shows Štefánik's kindness, which is emphasized through his work for humanity and pure patriotic efforts:

Milan: I have this idea; even I have also talked about it with the local governor, so buy one of the islands ${ }^{5}$ here and move here all Slovaks.

Missionary: And how? 'On wooden carriages'? Or troughs?

Milan: At least they would not live under foreign oppression. (pp. 19-20)

A scene of tender irony, for example, depicted Štefánik introduces Masaryk to society in Paris and everybody in Paris is interested in him and not in our 'daddy', something which never happened to Masaryk before.

The libretto of M. R. Štefánik by Šoth and Mistríková (2009) cannot be analyzed in terms of character creation because the character was mainly depicted for the stage production. The libretto contained only a brief characterization of events in which Štefánik finds himself. Šoth and Mistríková (2009) show there is allusion as far as the nature, personality, and character: "14. M. R. ŠTEFÁNIK comes to Tahiti to build an observatory. He gets himself acquainted with local South Pacific culture and he meets a terminally ill girl." (Šoth \& Mistríková, 2009, not numbered).

All of the productions have a type of panoramic character, which was underlined in the dance theater show, $M$. R. Štefánik, by adding the film projection of images which, in both real and imaginary dimensions, emphasized the historical and partly monumental tone of the whole composition. The beginning of the production (and the conclusion, with its variants) almost symbolically reflect the intention of its creators, which, according to their own explanations, mainly sought to present to the Slovak public (the academicians, high school audience, and the general public), Štefánik as an extremely important figure in their lives. The creators used the most well-known visual features of Štefánik's persona: the general's hat, statue, and pedestal.

\section{This is the Staging Description of the Situation}

On an empty stage, a fully illuminated figure in a long coat with a general's hat on his head gradually emerges up to the depth of the stage. The figure is tall like the Štefánik statue on a pedestal (portrayed by another icon, this time the ballet, an important Czech ballet master, Vladimír Harapes). Before its emergence, however, only a cone of light appears and at the 'discovery' the light shines over Štefaník's head, reminiscent of an aura.

The composition of the production, which is based on the succession of ballet, visual, and parts that balance each period of Štefánik's life, including his stay in France. It is similar to the other two productions based on the succession of important parts of Štefánik's life, intertwined with singing, dancing, drama, and artistic image output.

The performance created in Nitra, Štefánik - Slnko v zatmení (Štefánik - Solar Eclipse), is also biographical. Nonetheless, it is the first performance that is a dramatic play. Stefanik's life is presented in 25 images, from the time he was expelled from home by his father to his tragic accident. However, dramatic text is not strictly narrative. Biographical and factual passages are intermitted by the character of The First and The Second who join the images with often humorous or comical scenes. In these scenes, some facts from Stefanik's life are explained in more detail or help to evoke the atmosphere of the period he was in (for example they are waiters in a café in Prague, they climb Mt

\footnotetext{
${ }^{5}$ Notes from the author: Štefánik is at Tahiti.
} 
Everest along with him, and they are soldiers). The dramatic text presents some historical documents about Stefanik's life, namely, his letters, notes about significant events, and speeches. The play becomes more metaphorical in structure towards its end. For example, The First and The Second discuss various causes of the accident. The ending of the last scene is devoted to Stefanik's speech where the audience is addressed directly. This speech in Borušovičová (2017) is similar to the actual historic speeches he wrote, but it contains genuine political allusions:

ŠTEFÁNIK: Everybody wants to find the cause of my death. And just a few people care about my life and my beliefs. When I died, many people felt relief. The library I had had in Paris was plundered. The same happened to my art collection. Suitcase I had worn got lost. What remained is the state you live in. You can speak Slovak and you are free. Please do not plunder this state and remain free. I believe in you, my people. I believe you'll manage. You '11 manage without me. It's because I have to go now. (s. 106)

Štefánik 'makes' a rose as if by magic and puts it on the stage. He puts his hands into his pockets and is humming a song quietly then he departs. The first and last scene are created scenographically as a large solar disk that becomes darker and darker symbolizes the solar eclipse. This image creates the line between his passion for astronomy and his own destiny.

Productions are quite different from the perceptive point of view. On the one hand, the productions, General and Štefánik - sokolar Eclipse, almost need no readiness of the audience for discernment. The bulletin and its narrative character met all the basic criteria of biographical dramas (contains all essential life facts of the displayed figure). On the other hand, the staging of $M . R$. Štefánik requires a more informed audience, because dance forms cannot present biographical facts in a consistent narrative way, as is apparent in the nature of ballet and other dance arts. The libretto, which is typical for this type of dramatic structure, can only minimally guarantee 'readability' of the text and the estimated realization of the meaning of the production. The Last Flight requires the most knowledgeable audience. Without, at least, basic knowledge of Štefánik's life with all its adventures and 'betrayals', it would be difficult to absorb the nature of the dialogue. This performance also presents Štefánik's personality in a most extreme way, does not try to over-idealize him. However, the positivity of his actions and life plays a critical part.

The panoramic nature of all three productions suggests that their authors considered it their duty to present his whole life (analogical opinions and philosophy) because not enough was known about him. If they had to consider him as a sufficiently well-known personality, they would have used another customary biographical model, a thorough analyzes into the critical life situation.

Critical and professional reflection of all three productions clearly embraced not only the topic but also the means of expression. They often emphasized a non-standard approach to the portrayal of his life, the depth of processing, and the artistic imagination and originality of each. Negative criticism of character or play or of Štefánik's personality is exceptional.

The only Slovak playwright who returned to the personality of Milan Rastislav Štefánik three times was Ján Solovič. In 1995, he published the text, Bližšie k slnku (Closer to the Sun), in which he deals with the period in Štefánik's life when he worked in Tahiti as an astronomer and intended to observe the transit of the comet Haley. This was not achieved because of poor weather conditions and thus Štefánik stayed in Tahiti with the consent of his supervisors for one more year to document the solar eclipse. Solovič (1995) depicted Štefánik creating his own Christmas crib and praying alone, during the Christmas period:

ŠTEFÁNIK: (After a while, he kneels down on the wooden step under the Christmas crib, folds his hands in prayer and speaks the words of the song quietly.)

What is our human power?

It cannot save us by itself.

But the Lord is here with us,

$\mathrm{He}$ is our shield in every fight.

Do you ask who is he?

Jesus, the Son of God.

He shall save the world,

He's the only God, 
He shall win the fight at the end. (XII) ${ }^{6}$

The play has a spiral-like composition. In the beginning, Štefánik meets one of the great admirers of his scientific work, a physicist and technician, Aurel Stodola. In the closing scene, Stodola meets Einstein immediately before he is awarded a Nobel Prize, and reminds him of his personal meeting with Štefánik and informs him of his death.

The second play Bez čiernej skrinky (Without the Flight Data Recorder) by Solovič (1998, s. 287-354) depicts Štefánik differently. It is a fictive and hypothetical story which through 16 dream-like images answers the question of what would happen if Stefánik had not died in a plane accident but rather his double. There were only four characters in the play and only Štefánik's character is depicted realistically; other characters are shown more in a symbolic nature. Štefánik (Emil Štefek) lives his calm life in one of Bratislava's squares in a tobacco-store that he gained as a former legionary. $\mathrm{He}$ lives through various periods of his commemoration as a national hero but he rarely comments on what is happening around him. Solovič (1998) depicts the one exception to this rule is the Second World War:

ŠTEFÁNIK: Children conceived in the besetment of piece have grown now. They can send them to fronts all across the world. Frightful vision. How happy we were to hear the gun salutes celebrating victory, thinking there was no more shooting ahead of us.

JULIANA: I can hear the shooting.

ŠTEFÁNIK: And again, there are innocent people dying. I had rather gave up reading newspaper. (p. 330)

In the third play by Ján Solovič called Herostrates a hviezdy (Herostrates and the stars) which was staged in The Theatre of Ján Palárik in Trnava and directed by Michal Babjak, Štefánik emerges only as one of three minor historical characters. Along with Ludovít Štúr and Matej Bel, he is presented at the court trial with a vandal who destroyed their statues and caused the heart attack of a witness who was outraged by his deeds.

In 2014, there was a dramatic reading called Štefánik? Štefánik! premiered in Portheimka Gallery in Prague. The author and director, Irena Žantovská, created the work with a biographical character. The reading was a combination of facts, which spectators could hear from the radio and entrances, of the actor who read from Štefánik's letters to his parents, mother, sister, and his beloved last love, Giuliane'de Benzoni, or from the records of some important events or speeches. The opening monologue of the actor was stylistically different. It contained the author's motivation for writing the text. The screenplay was written and interpreted bilingually, both in Czech and Slovak languages.

\section{Conclusion}

The theater is associated with the personality of Štefánik not only with regard to efforts to 'disenchant' the personality in our culture but also in relation to his unexpected, surprising, and controversially interpreted death in 1919. Many of the mentioned plays react differently in their plot to precisely this ambivalence. Various theatrical artifacts that have been analyzed attempt to show Štefánik's personality from an extremely theatrical point of view and at the same time as an interesting topic that continually inspires. The main reason is certainly that Štefánik's life was filled with highly dramatic events from the theatrical point of view and all of it is still fundamentally affecting people's thinking, social and political lives, and position in Europe and the world. Theatre plays about him that appeared during the last decade do not just fill loopholes in the theater map of important personalities of all times. They allow one to enter this map and hold discussions due to their form, materials, and basic idea.

The most striking feature of the analyzed portraits of Štefánik is the understanding of the dramatic forms of him as a symbol of national pride, highlighting his ability of tenacious work to achieve the objective and the love of his native country. The plays that are created today start to depict him in another crucial dimension, as a representative of cosmopolitanism. They emphasize his cultural scope of knowledge, versatile interests, and understanding of the problems of different peoples and language skills (Inštitorisová, 2014, p. 225). These plays and stage productions are important in terms of

\footnotetext{
${ }^{6}$ It is a citation from the evangelical song named Hrad prepevný je Pán Boh nášs (The Lord is Our Strong Tower).
} 
intercultural aspect. Whether they are references to Štefánik's life in France or Tahiti, they display his method of thinking and living in other cultures.

Comparing the method of imaging personality of Milan Rastislav Štefánik with others, either with Slovak or foreign personalities, the character of Štefánik in itself still contains the traditional features of his personality and he is represented primarily as a figure of great historical importance, which one does not forget. A semiotic point of view, however, suggests that he is a little rooted in the consciousness of the Slovaks.

\section{References}

Balák, K. (1936). 4. V. 1919. In Milan Rastislav Štefánik. Praha, Czech Republic: Nakladatel F. Švejda, p. 9-13. Bondy, E. \& Kmet'ová, E. (2001). The Last Flight. Twelve Views of M. R. Š. [Posledný let. Dvanást' pohl’adov na M. R. Š.] [Libretto.] [Manuscript.] Bratislava, Slovakia: Združenie pre súčasnú operu.

Borušovičová, E. (2017). Štefánik - Solar Eclipse [Štefánik - slnko v zatmení.] [Scenario.] [Manuscript.] Nitra, Slovakia: Divadlo Andreja Bagara.

Germain, A. (1940). Štefánik. Trnava, Slovakia: Urbánkova divadelná knižnica.

Inštitorisová, D. (2012). M. R. Štefánik dans la création théâtrale en Slovaquie [Osobnost' M. R. Štefánika v divadelnej tvorbe na Slovensku]. In E. Melušová \& S. Benčič (eds.). Inaua ad linguas hominesquereserata IV. La porte des langues sóuvres aux hommes IV. Brána jazykov k l’ud’om otvorená IV. Paris, France: Impress, pp. 43 - 53.

Inštitorisová, D. (2014). Milan Rastislav Stefanik in the Slovak and Czech Drama Creation [Postava M. R. Štefánika v slovenskej a českej dramatickej tvorbe]. In I. Pospíšil \& A. Zelenková (eds.). Thought Literatures in Czech-Slovak Relations (Past and Present) [Myšlenkové toposy literatury v česko-slovenských souvislostech (minulost a současnost)]. Brno, Czech Republic: Tribun EU, s. r. o., pp. 219-228.

Jariabek, O. (1933). Milan's Victory and Death [Milanovo vít'azstvo a smrt']. In A. Zbavitel (Ed.). Week of Štefánik's Celebration. [Týžden̆ Štefánikových osláv]. Žilina, Slovakia: Učitel'ské nakladatel'stvo O. Trávníček, 1933, pp. 153-172. Macho, P. (2010). About Štefánik's monument in Trnava [K vzniku Štefánikovho pomníka v Trnave]. In M. Čaplovič \& B. Ferenčuhová \& M. Stanová (eds.). Milan Rastislav Štefánik in light of historical sources and latest findings of historiography [Milan Rastislav Štefánik v zrkadle prameňov a najnovších poznatkov]. Bratislava, Slovakia: Vojenský historický ústav, Historický ústav SAV Bratislava, Slovenský národný archív Bratislava, pp. 242-243.

Macho. P. (2011). Milan Rastislav Štefánik in the Heads and Hearts. The Phenomenon of a National Hero in a Historical Memory [Milan Rastislav Štefánik v hlavách a v srdciach. Fenomén národného hrdinu v historickej pamäti]. Bratislava, Slovakia: Historický ústav SAV.

Merlínová, L. (about 1926). Loved by Gods. [Bohy milovaný]. Praha, Czech Republica: Nakladatel F. Švejda.

Miko, E. (1943). Štefánik's message [Štefánikov odkaz]. In E. Miko (Ed.). We're celebrating [Oslavujeme]. Prešov, Slovakia: Nakladatel'stvo Ludovíta Šmigala, pp. 89-90.

Mistrík, M. (Ed.) (1999). Slovak Theater in the 20th Century. [Slovenské divadlo v 20. storočí]. Bratislava, Slovakia: VEDA.

Sabov, P. (2010). The fate of General Milan Rastislav Štefánik's personal library and its current state [Osudy osobnej knižnice generála Milana Rastislava Štefánika a jej súčasný stav]. In M. Čaplovič \& B. Ferenčuhová \& M. Stanová (eds.).

Milan Rastislav Štefánik in light of historical sources and latest findings of historiography [Milan Rastislav Štefánik $v$ zrkadle prameňov a najnovšich poznatkov]. Bratislava, Slovakia: Vojenský historický ústav, Historický ústav SAV Bratislava, Slovenský národný archív Bratislava, pp. 263-267.

Solovič, J. (1995). Closer to the Sun [Bližšie k slnku]. In Javisko, 27(7/8). Annex. Repertoire [Príloha. Repertoár]. Solovič, J. (1998). Without the Flight Data Recorder [Bez čiernej skrinky]. In A. Mat’ašík (Ed.). Contemporary Slovak Drama 1997-1998 [Súčasná slovenská dráma 1997-1998]. Bratislava, Slovakia: Národné divadelné centrum, pp. 287-354. Šoth, O. \& Mistríková, Z. (2009). M. R. Štefánik. [Libretto.] In M. R. Štefánik. Košice, Slovakia: Štátne divadlo. [Not numbered.]

Štefánik, M. R. (1935). Notebooks M. R. Štefánik's. [Zápisníky M. R. Štefánika]. Praha, Czech Republic: Nakladatelství památniku osvobození.

Štefko, V. (Ed.) (2001). History of the Slovak drama of the 20th century. [Dejiny slovenskej drámy 20. storočia]. Bratislava, Slovakia: Divadelný ústav.

Štepka, S. (2003). General. The Story of the Little Big Man [Generál. Príbeh malého vel'kého muža]. [Scenario.] Bratislava, Slovakia: Radošinské naivné divadlo. [Manuscript.]

Šujan, J. (1928). Milan Rastislav Štefánik. Age of youth. [Milan Rastislav Štefánik. Vek mladosti]. Praha, Czech Republic: Aventinum.

Vránek, Č. (1933). Štefánik's Mother [Matka Štefánikova]. In Č. Vránek (Ed.). Scenes to Štefánik's celebrations. [Scény k Štefánikovým oslavám]. Žilina, Slovakia: Učitel'ské nakladatel'stvo O. Trávníček, pp. 13-22.

Zemančík, O. (1938). Hero's Message [Hrdinov odkaz]. In O. Zemančík (Ed.). M. R. Štefánik (May 4) [M. R. Štefánik (4. máj)]. Bratislava, Slovakia: Universum, pp. 46-50.

Translation: PhDr. Miroslava Mates, Mgr. Dana Gálová, PhD. 